\title{
تأثير تمرينات خاصة في تطوير القدرة الانفجارية للذراعين و دقة ههارة الإرسال في التنس الأرضي للاعبين تحت(10) سنة
}

\author{
م.م خاله علي هسبون \\ كلية التربية الرياضية/ هامعة واسط \\ تمركزت مشكلة الباحث من خلال ملاحظة الباحث كونه لاعب سابق ومدرب حاليا للعبة التنس الأرضي تبين أنه اغلب المدربين \\ مط:ص البهث

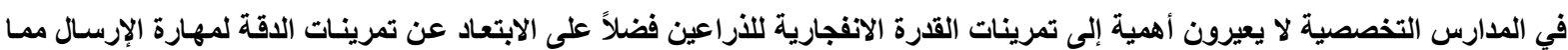

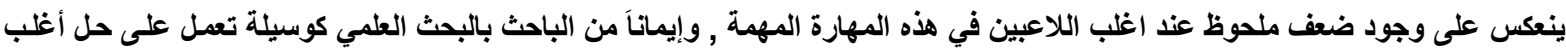

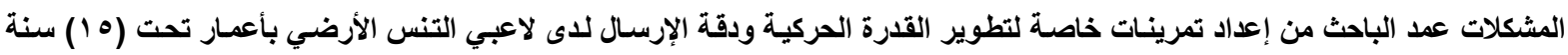

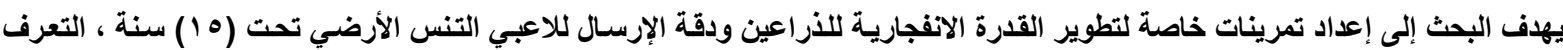

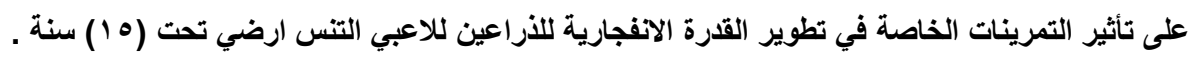 \\ إستعمل الباحث المنهج التجريبي بتصميم (المجموعتـان المتكافئتـان ذات الاختبـار القبلي والبعدي) وذلكـ لملاءمتـه طبيعة المشكلة \\ وتحقيق أهداف البحث مثلت عينة البحث مجتمع البحث بأكمله وهم لاعبو المدرسة التخصصية بالتنس الأرضي بأعمار تحت 10 سنة للموسم

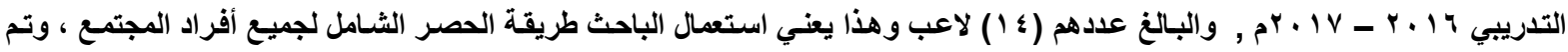 \\ تقسيمهر عن طريق القرعة إلى مجموعتين الأولى تجريبية وضـابطة ولكل مجموعة (V) لاعبين. ومن أهم الاستتتاجات التي توصل اليها \\ الباحث هو ظهور تأثير إيجابي في تطور القدرة الانفجارية للأراعين بأستخدام التمارين الخاصة للمجموعة التجريبية وظهور تأثير إيجابي في

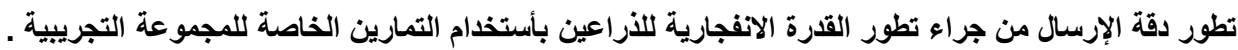

he effect of special exercises in the development of the explosive capability of the arms and the accuracy of the skill of sending in tennis to players under $(10)$ years

Khaled Ali Hassoun

Summary

The researcher's problem focused on the observation of the researcher as a former player and currently coach of the tennis game proved that most trainers in the specialized schools do not attach importance to exercises explosive capacity of the players as well as to stay away from the exercise accuracy of the skill of transmission, which reflects the presence of weakness marked by most players in this important skill, And the belief of the researcher scientific research as a means of solving most of the problems, the researcher to prepare special exercises to develop the speed of motor and accuracy of the transmission of tennis players under the age of $(10)$ year The aim of the research to prepare special exercises to develop the explosive capability of the arm $\mathrm{N}$ accuracy transmitter for tennis players under the ground (10) years .altaraf on the effect of exercise for the development of the explosive power of arms for tennis players under the ground $(10)$ years. The researcher used the experimental method in designing (the two equal groups with tribal and remote test) in order to suit the

nature of the problem and achieve the research objectives. The sample of the research represented the entire research community. They are the players of the specialized school in the ground tennis under the age of 10 for the training season Y. I Y Y. IV. The researcher used the method of comprehensive enumeration of all members of the society, and were divided by lot into two groups, the first experimental and the control of each group $(\checkmark)$ players. One of the most important conclusions reached by the researcher is the positive effect on the development of the explosive capacity of the arms using the special exercises of the experimental group. A positive effect in the development of the accuracy of the transmission due to the development of the explosive chest of the arms using special exercises for the experimental group. 


\section{الباب الأول}

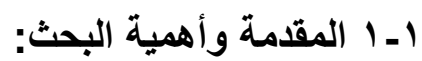

يُشكل التقدم العلمي الكبير ثمرة كبيرة للعلماء و المختصين في مجالات العلوم المختلفة, ويهينـا في

هذا المقام أن نسجل مجالات التربية الرياضية تحتاج إلى الكثير من المراجع و المؤلفات العلمية لملاحقة هذا

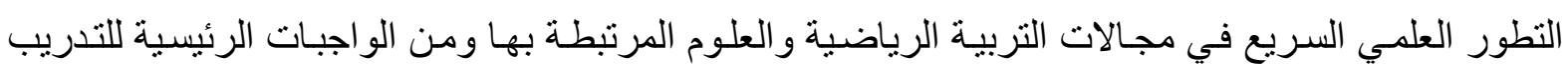
الرياضي الوصول بالرياضي وخاصة النانثئ لأعلى مستوى، وذللك من خلال بنـاء المتطلبـات المهاريـة والبدنية و الوظيفيـة والنفسية، وتحسينها وتطوير هـا إذ تعد المتطلبـات المهاريـة و البدنيـة إحدى أهم الركـائز الأساسية.

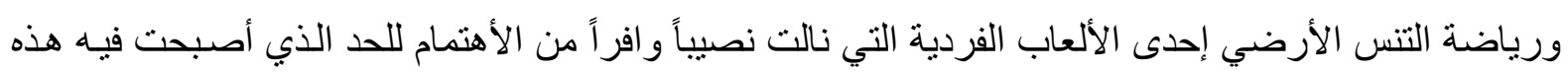

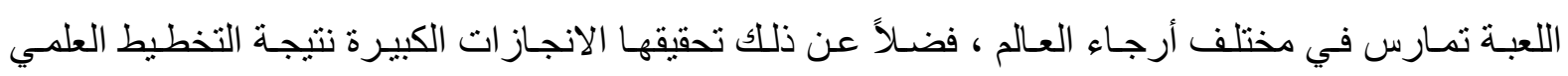
و استخدام الأساليب و الوسـائل المسـاعدة المتعددة التي تعمل على إكتسـاب المهار ات الحركية وتطوير هـا بشكل أكبر و أسرع للوصول إلى الاقتصاد في الجهد و النفقات.

من أولى منطلبات لعبة التنس تطوير صفاتها البدنية الخاصة بالقوة بأنو اعها الانفجاريـة والمميزة بالسر عة

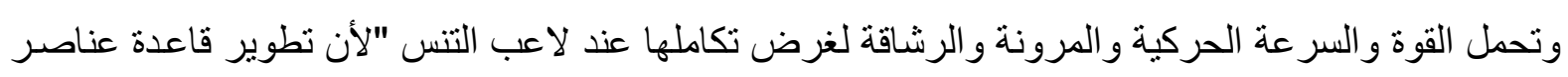

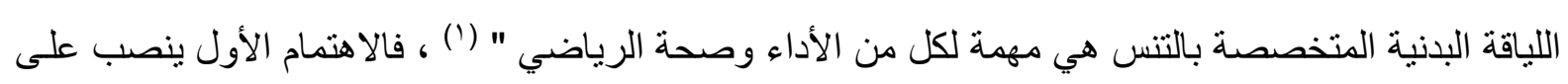
أستخدامات القوة لتطوير القدرة العضلية على الأداء الجيد ، وخاصـة أن المهارات الأساسية للعبـة التنس تسـاهم

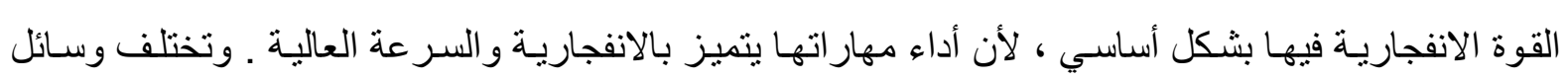

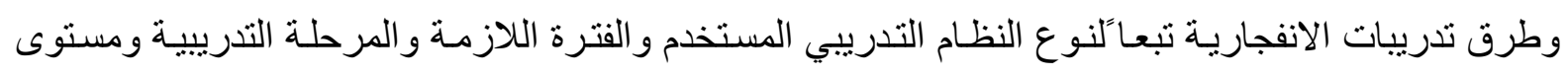

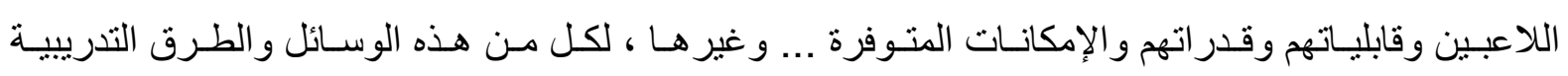

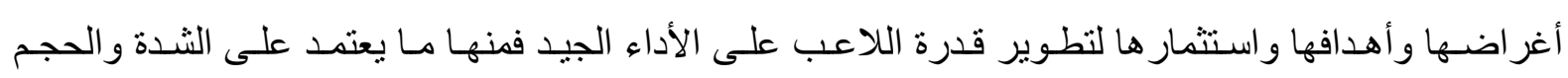
و التكر ار و التنوع ونسب الر احة و الممارسة والفترة الزمنية اللازمـة للتدريب وجميعها تصب في تطوير اللياقة البدنيـة والمهاريـة وحسب منطلبـات تلك اللعبـة ولكن بشكل مغـاير الواحدة عن الأخرى ، في حين أثـارت

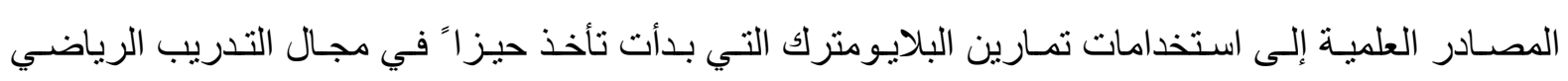
وتشارك بنسبة كبيرة في نطوير عناصر القوة الانفجارية والقوة المميزة بالسرعة الحركية والانتقاليسة و غيرهـا ، ولعبة التنس من الألعاب التي تحتاج إلى هذا النوع من التدريبات في تطوير القوة الانفجارية للذر اعين و الرجلين لما لها من أهمية كبيرة في اللعب . ويعد الارسال من المهار ات الأساسية والتي تعد العمود الفقري للعبة حيث يستطيع المرسل وضع اللاعب المنافس تحت الضغط وتعطي المرسل زمام قيادة المبار اة لذلك نجد إن كافة اللاعبين يختارون الإرسـال فيما إذا ربحوا القرعة.

أداء الإرسال بشكل جيد يؤدي إلى زيادة فرصـة اللاعب بـالفوز في المبار اة بأقل مـا يمكن من المجهود

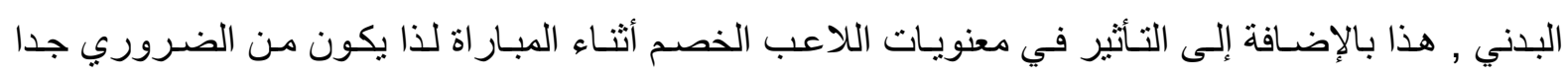


الاهتمام بمهارة الإرسال و التدريب عليها بشكل مستمر وبمـا يضمن إتقانها على مستوى عالٍ من الثبات في الأداء."(') وتكمن أهمية البحث في تطوير القدرة الانفجارية للذر اعين ودقة الإرسـال من خـلال إعداد تمرينات

$$
\begin{aligned}
& \text { خاصة للاعبي التنس الأرضي بأعمار تحت (10) سنة . } \\
& \text { ا }
\end{aligned}
$$

من خلال ملاحظة الباحث كونه لاعب سابق ومدرب حالياً للعبة التنس الأرضي تبين انه اغلب المدربين

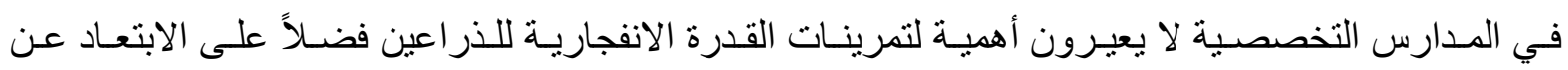
تمرينـات الدقة لمهارة الإرسـال ممـا ينعكس على وجود ضـف ملحوظ عند أغلب اللاعبين في هذه المهارة المهمهة , و إيمانـاً من الباحث بالبحث العلمي كوسيلة تعمل على حل أغلب المشكلات عمد الباحث من إعداد

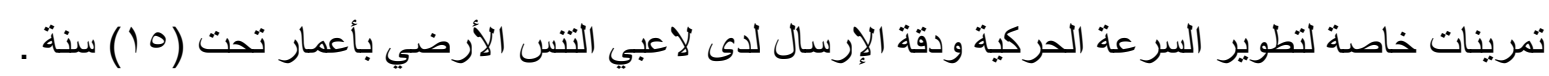

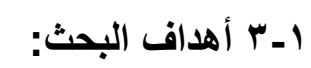

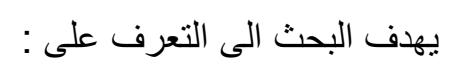

1 - إعداد تمرينات خاصة لتطوير القدرة الانفجارية للذر اعين ودقة الإرسال للاعبي التنس الأرضي تحت (0 1) سنة . זـ التعرف على تأثثر التمرينات الخاصة في تطوير القدرة الانفجارية للذر اعين للاعبي التنس الأرضي تحت (10) سنة rـ التعرف على تأثير التمرينات الخاصة في تطوير دقة الإرسال للاعبي التنس الأرضي تحت (0 (1) سنة.

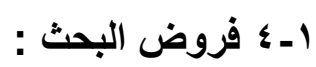

ا - توجد فروق دالة إحصـائية بين القياسـات القبلية والبعدية في القدرة الانفجاريـة للذر اعين للمجمو عتين الضابطة والتجريبية ولصالح القياسات البعدية .

r- توجد فروق دالة إحصائية بين القياسات القبلية والبعدية في دقة مهارة الإرسـال للمجموعتين الضـابطة و التجريبية ولصالح القياسات البعدية . r- توجد فروق دالة إحصائية بين القياسات البعدية للمجمو عتين الضابطة و التجريبية في القدرة الانفجاريـة للذر اعين ودقة الإرسال ولصالح المجمو عة التجريبية.

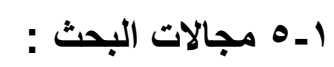

ــــ المجال البشري: لاعبو التنس الأرضي تحت (10 ) سنة في المدرسة التخصصية في محافظة بابل

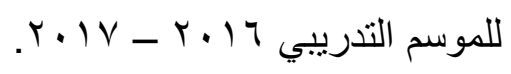

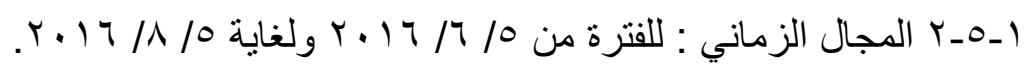
1 _- المجال المكاني: ملعب التنس الخاص في قاعة حمزة نوري في محافظة بابل . 


\section{الباب الثانى}

\section{r - الدراسات النظرية والششابهة:}

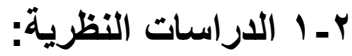

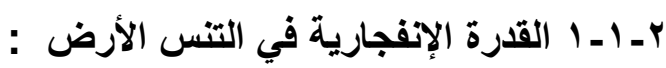

إن أغلب الألعـاب الرياضية تتضـمن أستخدام القوة الانفجاريـة ، حيث يتمرن الرياضيون النـاجحون

لغرض إنتاج قدرة انفجاريـة ، وتعني القدرة بأنها خليط يجهـ بين القوة ونسبة القوة على سر عة الحركة ، فحالات الألعاب المختلفة كضرب كرة البيسبول أو ضرب الكرة في التنس أو رمي القرص و المطرقة و القفز

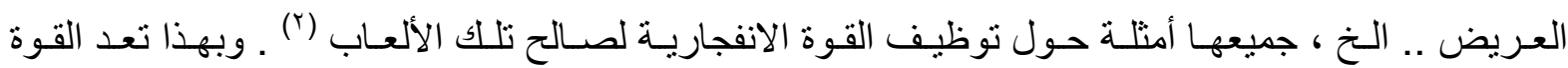
الانفجارية من القدرات البدنية المهمة في تطوير مهارات التنس وتظهر أهميتها كونها عنصر اء أساسياً في أداء ضربات التنس المختلفة التي تحتاج إلى قوة كبيرة لضرب الكرة , وبمـا أن مهار ات التنس تحتاج إلى السر عة القوية وتغيير الاتجاه و الدوران ، فقد ذكر ( Steven F... أن سرعة الحركة هي نتيجة القوة الانفجاريـة ، و هذا ما تؤكده حقيقة الاعتقاد أن القوة السريعة المتفجرة تستخدم كوظيفة أساسية في أداء المهارات الحركية التي تعتمد على السرعة والخفة والسر عة الحركية ، بالإضـافة إلى أن تغيير الاتجـاه يعمل بواسطة حركات التوقف الانفجارية التي تتفذ السر عة والقوة من خـلال تطويل العضـلات ، وإن تغيير السر عة والاتجـاه أيضـاء بتطلب تقصير العضلات بأسلوب مطاطي كرد فعل بصورة آنيـة مباشـرة بعد عملية تطويل العضـلات ، ولهذا يمكن التدريب على هذه الحالات من خـلال تدريبات البلايومترك الأفقيـة للمقاومـة الثقيلة و إختبـار ات القوة الانفجاريـة (َ) , ويضيف (علي سلوم) " أن الربط بين القوة و السرعة الحركيـة في العمل العضلي يعد من متطلبـات الأداء الرياضي في المستويات العالية ، وأن هذا العمل من أهم مـا يميز الرياضيين المتفوقين إذ أنهم يمتلكون قدرا" كبيرا" من القوة والسرعة ويمتلكون القدرة على الربط بينهما في شكل متكامل لأحداث الحركة السريعة ومن أجل تحقيق الأداء الفائق ، لذا بـات من المهم تنميـة القوة العضلية لضمان تنميـة صفة السر عة وتطوير هـا في رياضة التنس لتأثثير ها في الأداء " (๕).

وخلاصة القول يمكن التعبير عن القابلية في التحكم في السرعة ، وتغيير الاتجاه والتعجيل يتم إنجاز هـا من خلال أستخدام سرعة عالية للقوة الانفجارية التي يمتلكها الرياضـي من خـلال تدريبات عديدة وربمـا تكون أهمها تدريبات البلايومترك ، وترجع أهميـة القوة الانفجاريـة في التنس إلى أنها العامل في مهار ات دفاعيـة و وهومية حاسمة منها : - 2

ا - مهارة الإرسـال The Serve : تتطلب قوة انفجاريـة للذر اعين و الرجلين لمسـاعدة اللاعب بـالهجوم وتسجيل نقطة مباشرة أو وضع الكرة بشكل فعال . r- ـ مهارة الضربتين الأمامية والخلفية Fore Hand And Backhand Drive : و وذه تتطلب قوة انفجارية للذر اعين والرجلين لأداء ضربة قوية وطويلة أثناء الدفاع أو الهجوم و التحرك بسر عة بخطوات ثابتة 
r- الضربة الساحقة The Smash : ومن متطلباتها القوة الانفجارية باعتبار ها مهارة هجومية صرفه .

عـ - الضربات الطائرة The Volley : وجميعها تحتاج إلى قدرة إنفجارية للذر اعين متفاوتة أثناء الأداء.(0)

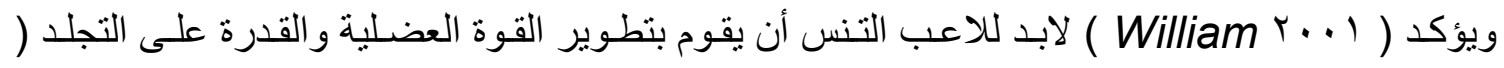

القابليـة على بـذل قوة ولقترة مـن الوقت ) وهذه تقود الرياضـي إلى التوصل إلى القوة العاليـة ، تحمل القوة وسرعة القوة أما ( . . . Donald Y ) فيعتبر أن أفضل طريق للتوصل إلى القوة الانفجاريـة يكون باستخدام تمرينـات البلايومترك (؟) ـ ولهذا أطلق عليها بعضهـم بأنها القوة المتفجرة أو القدرة الانفجاريـة والتي عرفها

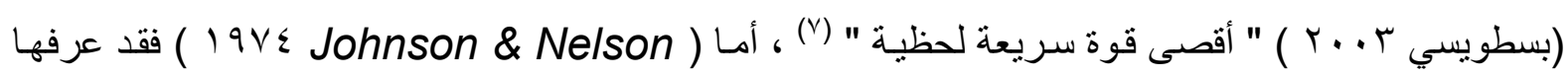
بأنها "القابلية على إخر اج أقصى قوة في أسرع زمن ممكن (^) .

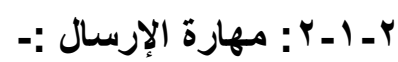

" تعتبر مهارة الإرسـال من أهم الضـربات في التنس الأرضـي وتعد كذللك اللعبـة الافتتاحيـة قبل

إحراز أي نقطة , كما إنها اللعبة الوحيدة التي لا يتنخل الخصم فيها , و التي يمكن تسجيل نقطة مباشرة منها."(')

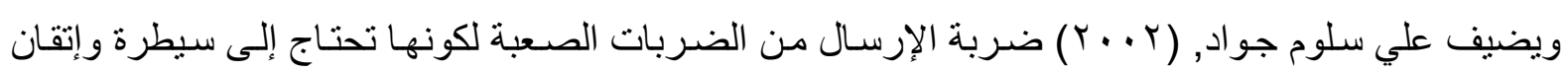
لكي يتمكن المرسل من تنفذيها ، ولكي يكون إرسالها ناجحاً يجب أن تؤدي عو امل التوجيه و السر عة و الدوران

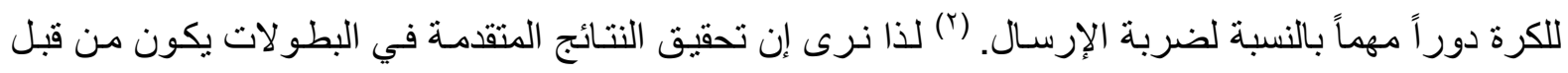

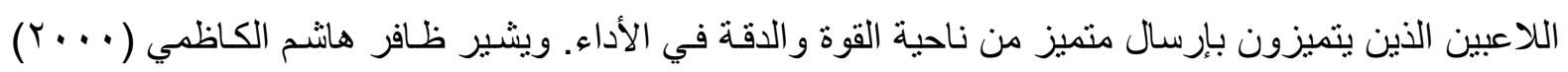
إلى إن " أداء الإرسال بشكل جيد يؤدي إلى زيادة فرصة اللاعب بالفوز في المبار اة بأقل مـا يمكن من المجهود

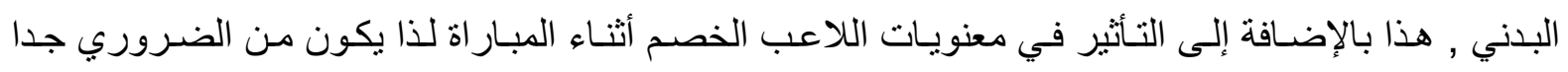
الاهتمام بمهارة الإرسال و التدريب عليها بشكل مستمر وبمـا يضمن إتقانها على مستوى عـالٍ من التبـات في

(')" الأداء." (1)

ويرى براون (990 (190) " انه لابد أن نعتني ونهتم بالإرسال ونتقنه جيدا لأن إرسالك إذا كان ضعيفا سوف

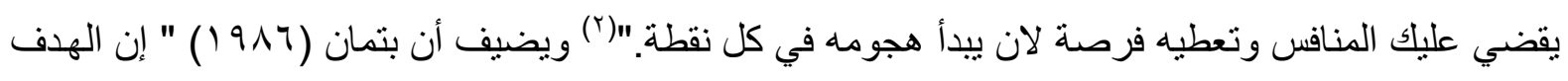
من الإرسال هو وضع الكرة في حالة اللعب بحيث يكون من الصعب على الخصم إرجاع الإرسال بقوة أو عدم إرجاعه على الإطلاق." () ولقد أكد هلال وآخرون إلى إن عملية الإرسـال تعتمد على خطوات عدة لأدائها

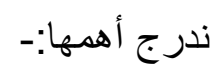
_ ثبات قذف الكرة واستقر ار ها ومر اعاة الارتفاع المناسب .

_ توقيت ملامسة المضرب للكرة مع تو افق المرجحة واستجماع الزخم الحركي ـ (؟) ويرى ظافر( . . . ب)" إن السبب لإمتلاك اللاعب أنو اعاً مختلفة من الإرسال هو في إيجاد طرق ومصسادر مختلفة يتمكن منها اللاعب في توقع اللاعب الخصم ويضعف من قدرته في إرجاع كرة الإرسال". (0) 
قام الباحث بتعليم الإرسال الدائري للمتعلمين كونهم من المبتدئين وهذا النوع من الإرسال مضمون النجاح

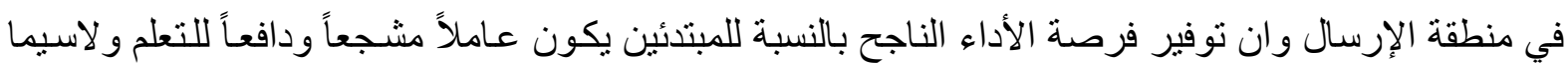
وأن له الأثر الملحوظ الواضح في تطور هذه المهارة هذا ما أكده هلال(1991) ) " أنـه يفضل أستخدام الإرسـال

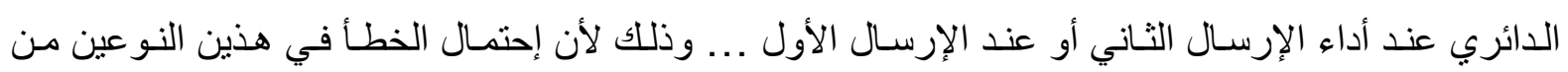

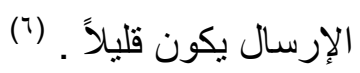

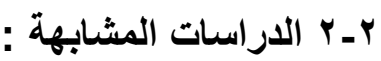

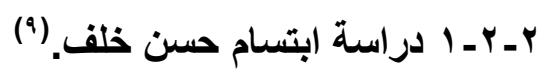

عنوان الرسالة: تأثير منهاج تدريبي لتطوير القدرة الانفجارية والسر عة الحركية الخاصـة على أداء بعض التض المهار ات في السكواش. هدفت إلى وضـع منهج تدريبي لتطوير القدرة الانفجاريـة السرعة الحركية الخاصـة بلاعبي السكواش والتعرف على تأثثر المنهج التدريبي في تطوير القدرة الانفجاريـة السرعة الحركيـة الخاصـة، و التعرف على تأثير تطوير القدرة الانفجاريـة السرعة الحركية في أداء بعض المهار ات في السكواش. وقد أستخدمت الباحثة المنهج التجريبي كأسلوب أفضل لحل مشكلة البحث لقد أستخدمت الباحثة إسلوب المجمو عات المتكافئة وهي المجموعة التجرييية و المجموعة الضابطة مرجعاً للمقارنة بينهما ، وحددت الباحثة مجتمع البحث

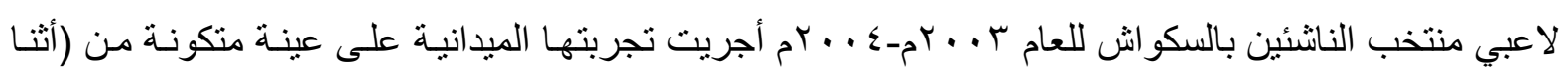

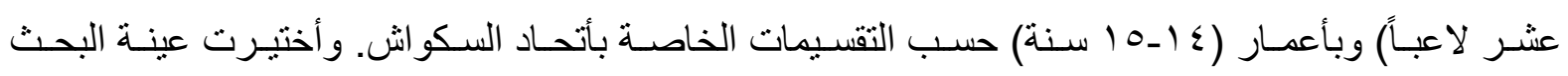
بالطريقة العمدية و التي مثلت هذه العينة نسبة مقدارها ( · ( (\%) من مجتمع الأصل للبحث و البالغ (Y I ) لاعباً وجرى توزيع اللاعبين بو اقع (T) لاعبين للمجموعة الواحدة بحيث أصبحت لدينا مجموعتان الأولى تجريبية و الثانية ضابطة واعتمدت الأسلوب العشو ائي في أختبار المجمو عتين وبطريقة القرعة وفي ضو غو النتائج التي لتي

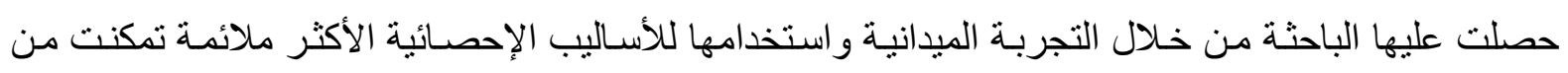
الوصول إلى الاستنتاجات أههرا أن للمنهج التدريبي المقترح اثر إيجابي في تطور مستوى بعض المهارات

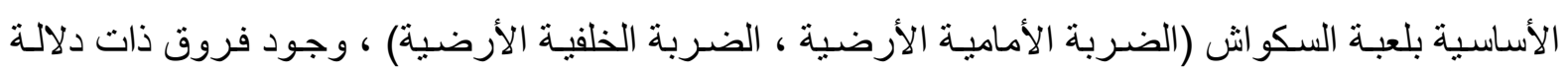

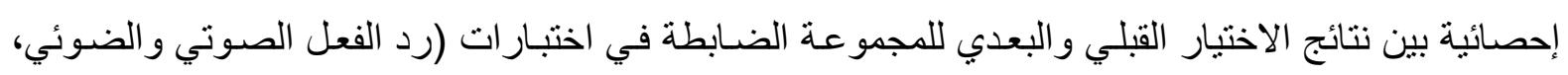
ركض • (م من الوضع الطـائرة السرعة الحركية للضربة الأماميـة السرعة الحركية للضربة الخلفيـة) وجود

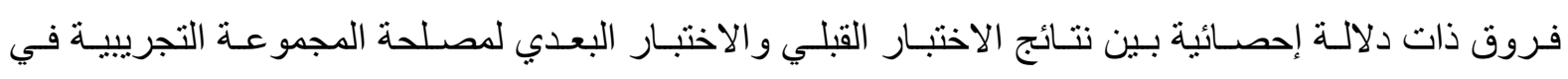
أختبار ات (رد الفعل الصوتي والضوئي ، ركض · ام من الوضع الطائر، السرعة الحركية للضـربة الأماميـة، السر عة الحركية للضربة الخلفية).

الباب الثالث ب- منهجية البحث وإجراع|ته الميدانية : rـ- امنهج البحث: إستعمل الباحث المنهج التجريبي بتصميم (المجموعتان المتكافئتان ذات الإختبار القبلي

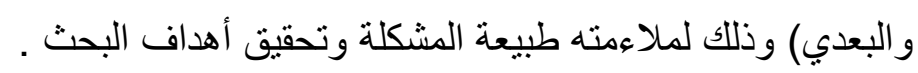




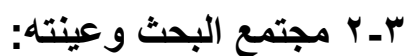

مثلت عينة البحث مجتمع البحث بأكمله وهم لاعبو المدرسة التخصصية بالتنس الأرضي بأعمار تحت 10

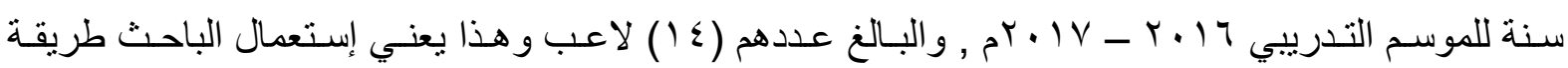
الحصر الثامل لجميع أفراد المجتمع ، وتم تقسيمهر عن طريق القرعة إلى مجمو عتين الأولى تجريبيـة وضـابطة ولكل مجمو عة (V) لاعبين ، وقد قام الباحثة بأجر اء التجانس لعينة البحث في المتغيرات التي قد يكون لها تأثير على نتائج البحث ، و هذه المتغيرات اشتملت على ( الطول ، الوزن ، و العمر التدريبي ) و عن طريق استخدام قانون معامل الالتواء وكما مبين في الجدول (

جدول ( 1 ) تجانس أفراد عينة البحث

\begin{tabular}{|c|c|c|c|c|c|c|}
\hline معامل الالتواء & الالمعياري & الوسيط & الوسط الحسابي & والقياس & المتغيرات & $ت$ \\
\hline., $71 Y=$ & $\cdot, \cdot \leq 9$ & $1,7 \ldots$ & $1,09$. & متر & الطول & $r$ \\
\hline$\cdot, 11 \leqslant-$ & $V, T Y$ & $01, \ldots$ & $0 \cdot, V I$ & كغم & الكتلة & $r$ \\
\hline$\cdot, r \leqslant V=$ & $\cdot, \wedge \theta$ & $\varepsilon, 0$. & $\varepsilon, \varepsilon r$ & سنة & العمر التدريبي & $\varepsilon$ \\
\hline
\end{tabular}

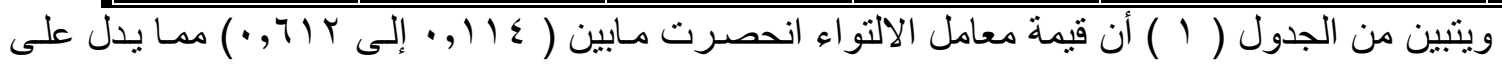

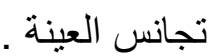

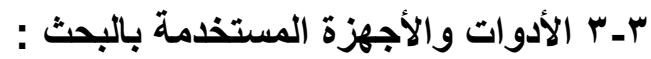

$$
\text { ملعب تنس أرضي . }
$$

كرات تتس عدد ( • ع ) نوع ( Teloon ) .

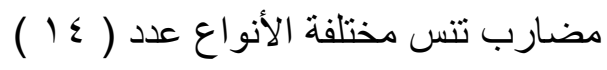

$$
\text { شريط قياس بطول ( · ( م ) . }
$$

شريط لاصق ملون عرض ( • (1 سم ) .

$$
\text { مسطرة وأدوات مكتبية . }
$$

طباثبير ملون .

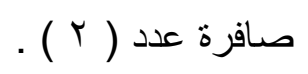

كر ات طبية زنة ( ( ، r ، r ) كغم عدد ( ) ) لكل كرة .

صندوق لجمع الكرات ( Box Balls ) .

ساعة توقيت .

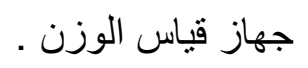

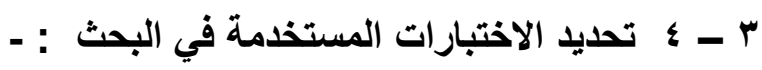

تجمع المصادر العلمية عند أختيار الاختبار ات أن تكون موضوعية وذات صدق وثبات وأن تكون وثثية الصلة بموضوع أهداف البحث وملائمة لعينته ، ومن خلال إطلاع الباحث على العديد من الدراسـات والمر اجع العلمية المختصة في التدريب الرياضي تم تحديد اختبار رمي الكرة الطبية زنة (؟) كغم باليدين من فوق الر أس 
من وضع الجلوس على الكرسي بهدف قياس القدرة الانفجارية للذر اعين , واختبار مهارة الإرسـال وتم عرضـه

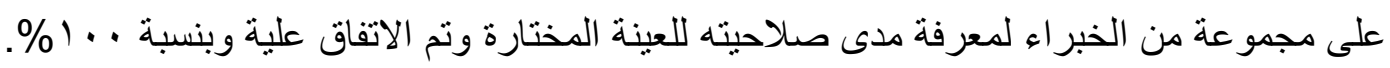
بـ بـ توصيف الاختبارات:

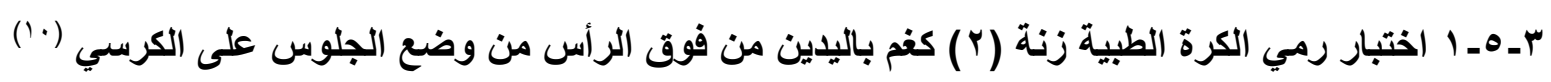
الهدف من الاختبار : قياس القدرة الانفجارية للذراعين.

الإمكانات والأدوات : كرة طبية زنة ( r ) كغم وشريط قياس وكرسي مع حزام تثبيت الجذع ومحكم . مواصفات الأداء : يجلس المختبر على الكرسي والكرة الطبية محمولة باليدين فوق الر أس "الجذع ملاصنق لحافة الكرسي ، يوضـع الحز ام حول جذع المختبر ويمسك من الخلف عن طريق محكم وذلك لغرض منع ملع المختبر من الحركة للأمام أثناء رمي الكرة باليدين لتتم عملية رمي الكرة باليدين فقط دون استخدام الجذع ، لكل

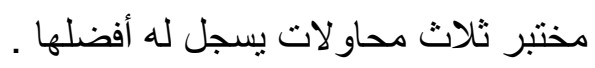
طريقة التسجيل : تحسب المسافة بين الحافة الأمامية للكرسي و أقرب نقطة تضعها الكرة على الأرض .

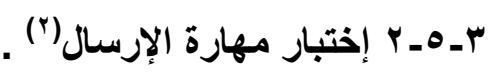
الهدف من الاختبار:- قياس دقة الإرسال في التنس الأرضي.

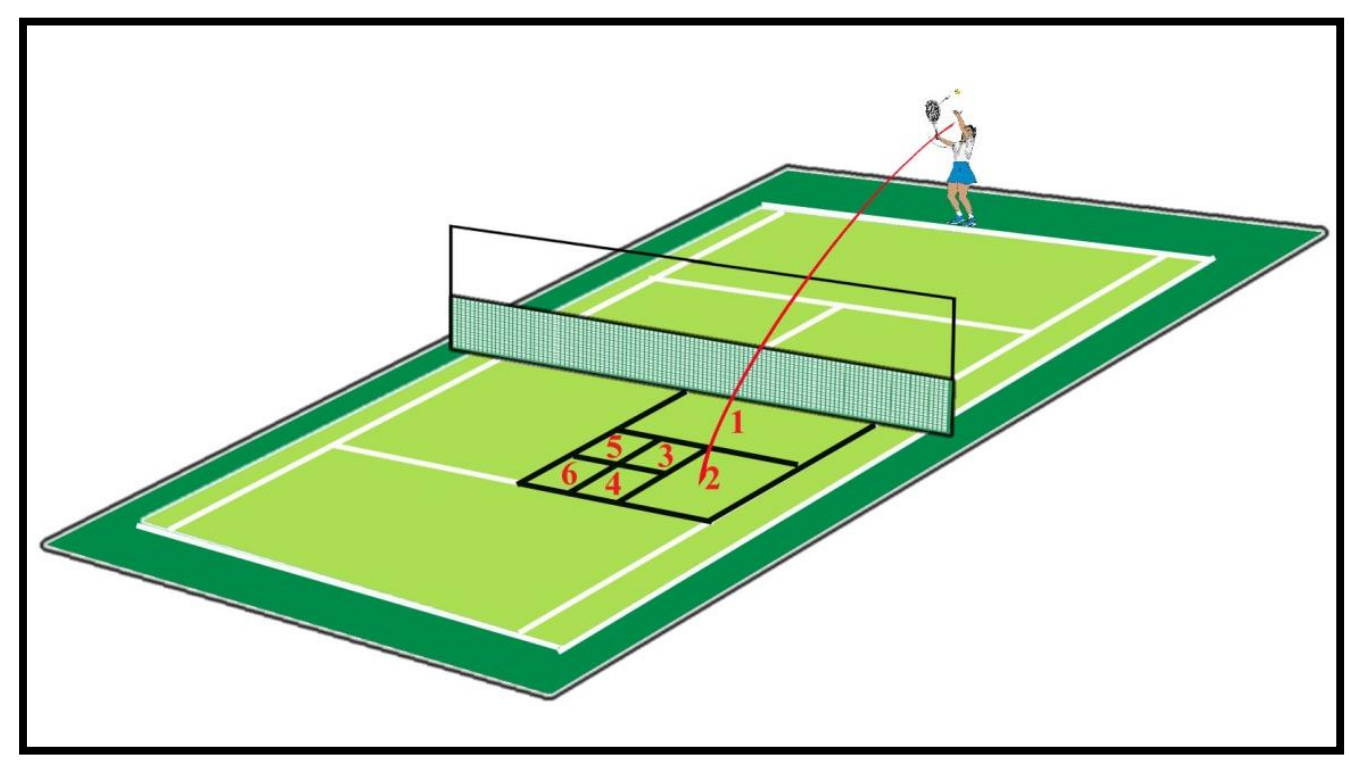

شكل ( (1) قياس دقة الإرسال في التنس الأرضي

- يثبت حبل قطره ( (، ) ) بوصة من طرفيه في قائمي الثبكة من أعلى , بحيث تكون المسافة بينه وبين

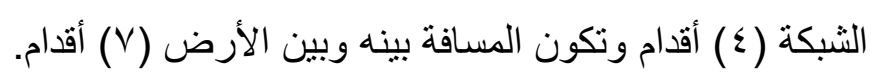

- - بعد فترة الاستعداد يقف المختبر خلف خط القاعدة المخصصـة لأداء الإرسـال للعب الفردي ثم يمنح خمس محاو لات تجرييية وبعد تنفيذها ، يخصص لكل لاعب عشر محاو لات إرسال يجب أن تسقط الكرة عندها

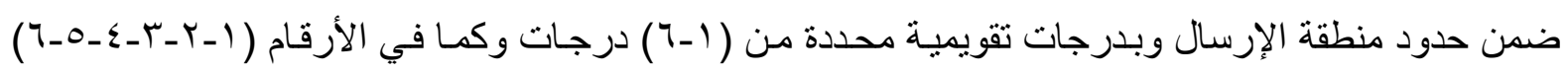
التي تمثل قيم تثير الى منطقة الإرسال . 


$$
\begin{aligned}
& \text { الرقم (1) يشير إلى مستطيل (10 10 ب 1 ) قدم . }
\end{aligned}
$$

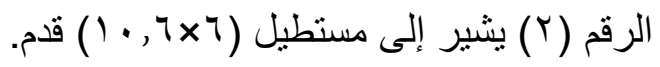

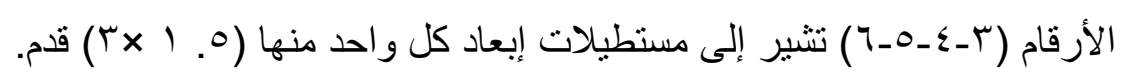

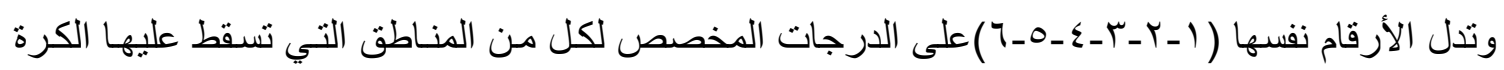
بشرط أن تمر بين الثبكة و الحبل . - الكرات التي تمس الحبل أو الثبكة لا تحسب محاولة وتعاد ثانية ـ ـ الكرة التي تمر أعلى الحبل تحسب محاولة وتمنح الدرجة صفراً حتى لو سقطت على أي موقع صحيح - تحتسب فيه الدرجة في المنطقة الصحيحة التي تسقط عليها الكرة . - درجات اللاعبين هي مجموعة النقاط التي حصل عليها من المحاو لات العشر.

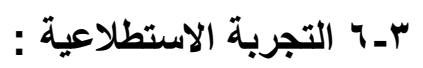

قام الباحث بـاجر اء التجربـة الاستطلاعية على عدد من لاعبي المدرسـة التخصصية والبالغ عددهم (0)

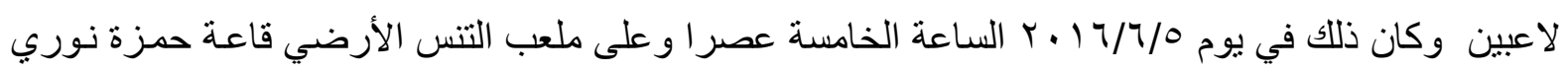
في محافظة بابل ، وكان الهدف من التجربة هو الاتي : تلافي المعوقات التي تواجه الباحث أثناء تنفيذ الاختبار ات . معرفة الزمن التقريبي الذي يستغرقه كل أختبار والوقت المستغرق لإجراء الاختبارات . التأكد من المعاملات العلمية للاختبار ات . التعرف على الوقت الملائم للتمارين المستخدمة . التعرف على ملائمة التمرينات لأفرد العينة.

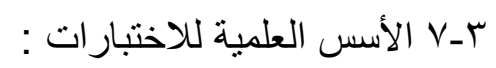

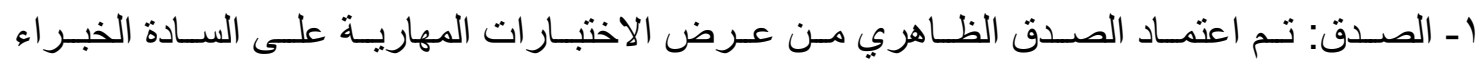
و المختصين * إذ تم اتفاق جميع الخبراء و المختصين عليها.

ז- الثبات: تم حساب معامل الثبات للاختبـار ات المبحوثة بطريقة (الاختبـار و إعادة الاختبـار) ، إذ طبّق

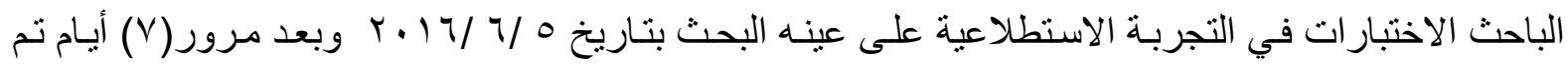

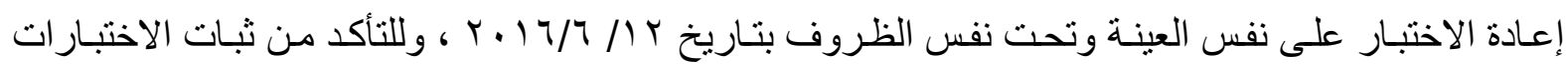
استخدم الباحث معامل ارتباط سبيرمان بين نتائج الاختبار الأول والاختبار الثاني، وقد أظهرت النتائج وجود

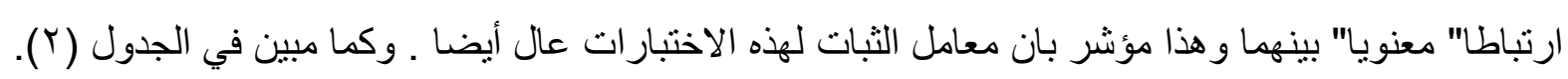


r- الموضوعية : لغرض التأكد من موضو عية الاختبار ات استعان الباحث بدرجات محكمين *جلت في

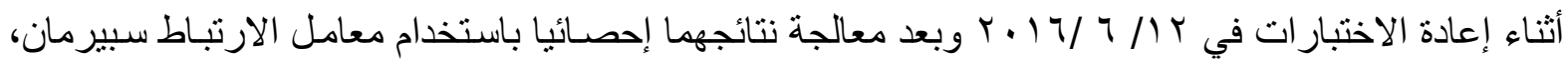

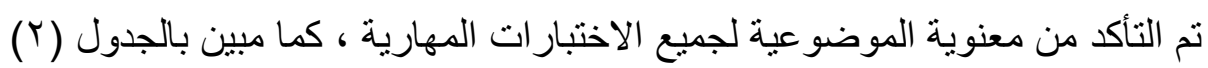

جدول (Y) يبين معاملات الثبات والموضوعية للاختبارات المبحوثة

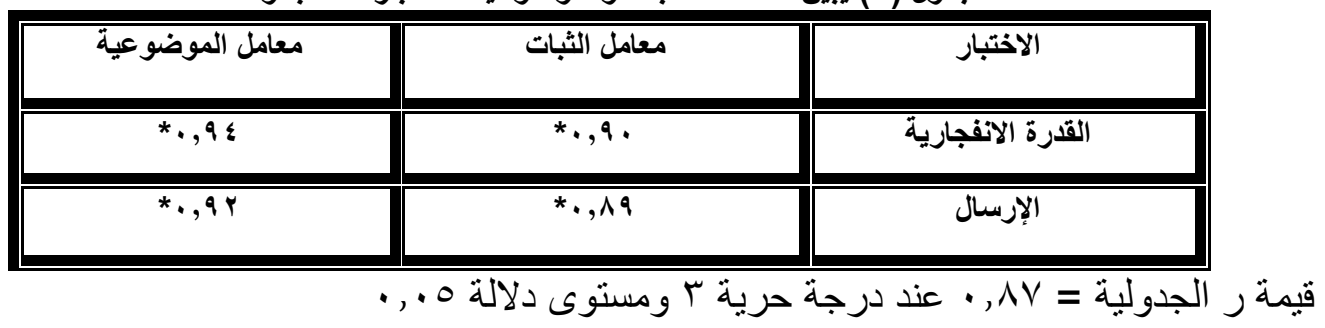

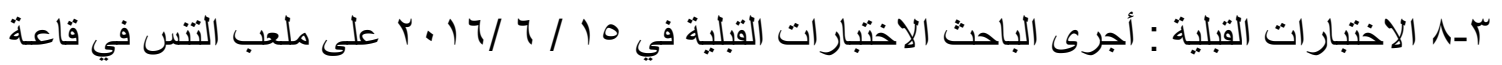
حمزة نوري التابع الى المدرسة التخصصية بالتنس الأرضي بمحافظة بابل الساعة (0) عصراً حيث قام الباحث باختبار الأرسال و القدرة الانفجاريـة بعد راحة أستمرت نصف سـاعة بين الاختبار الخـاص بالإرسـال والقدرة الانفجارية ، و عليه تمت عملية التكافؤ بين مجمو عتي البحث في جميع متغيرات الدراسة وقد تم استخدام اختبار ( ) للعينات غير المتناظرة والمتساوية بالعدد وقد ظهر عدم وجود فروق ذات دلالة معنويـة بين المجمو عتين الضـابطة والتجريبية نظر اء لكون جميع قيم ( ت ) المحتسبة كانت أصسغر من قيمـة ( ت ) الجدوليـة والبالغـة

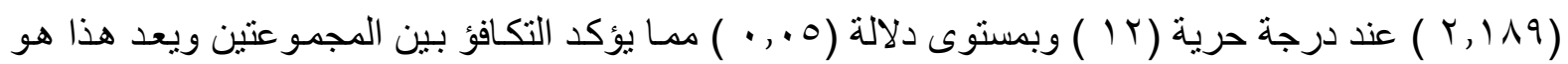
القياس القبلي وكما موضح في الجدول ( ) ) . الجدول ( ץ ) يوضـح الأوسـاط الحسـابية والانحر افـات المعياريـة وقيمـة ( ت ) المحتسبة للاختبار القبلي وللمجمو عتين الضابطة و التجريبية في الاختبار ات المبحوثة

\begin{tabular}{|c|c|c|c|c|c|c|c|}
\hline \multirow[t]{2}{*}{ الالالة } & \multirow{2}{*}{ قاتة } & \multicolumn{2}{|c|}{ التجريبية } & \multicolumn{2}{|c|}{ الضابطة } & \multirow{2}{*}{ القياس } & \multirow{2}{*}{ المبكيريزاتجات الإحصائية } \\
\hline & & $\varepsilon+$ & س & $\varepsilon+$ & س & & \\
\hline غير دال & $\cdot, 417$ & $\cdot, \leq \leqslant 7$ & $Y, 7 V I$ & $\cdot, r q 9$ & $r, V \leq r$ & متر & فوق الر أس من طبية زنة وضع الجلوس كفم منى \\
\hline غير دال & 1,11 & $r, 1 \wedge$ & $1 \%, \Lambda$ & $\overline{r, \otimes \Lambda}$ & 10,1 & درجة & الارسال \\
\hline
\end{tabular}

r ـ9 التمرينات الخاصة المعدة من قبل الباحث: تم إعداد تمرينـات خاصـة متنوعة ينظر (ملحق ؟) كان الغرض منها هو تطوير القدرة الانفجارية (Explosive power) لعضلات الذراعين ودقة الإرسال للاعبي

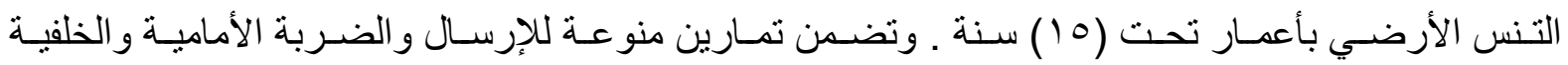
وباستخدام اتجاهات ومسافات وسرع مختلفة للتمرين الواحد , وتمرينات بلايومنرية لتطوير القدر الانفجارية.

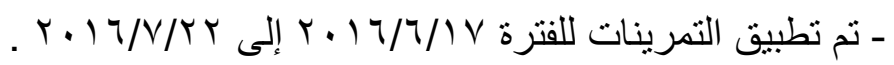
- مدة التمرينات (7) أسابيع بو اقع ثلاث وحدات إسبو عياً . 
ـ الزمن المحدد للتمرينات انحصر مابين ( • _ _ مب ) دقيقة من الجزء الرئيسي للوحدة التدريبية . ـ أيام المحددة للتدريب ( الأحد - الثلاثاء ـ الخميس) الساعة الخامسة عصراً . ـ الثدة المستخدمة تر اوحت مابين( • ـ ـ90\%).

طريقة التدريب المستخدمة : طريقة التدريب الفتري مرتفع الثدة و التدريب التكراري.

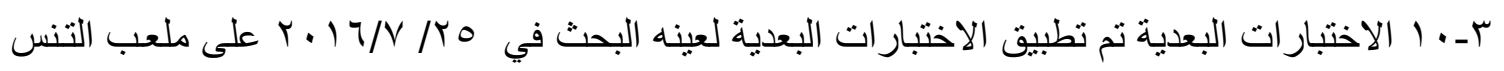
في قاعة حمزة نوري التابع الى المدرسة التخصصية بالتنس الأرضي بمحافظة بابل الساعة (0) عصر اً وبنفس لهُبـ الشروط التي تم إجر ائها في الاختبار ات القبلية.

r-T الوسائل الإحصائية : تم أستخدام الحقيبة الإحصائية (') (spss) في تحليل بيانات البحث وكما يأتي ـ الوسط الحسابي - الانحر اف المعياري - النسبة المئوية ـ ـ اختبار (T) للعينات المتزرابطة ـ اختبار (T) للعينات المتناظرة - معامل الارتباط سبيرمان.

\section{الباب البرابع}

ع-عرض النتائج وتحليلها ومناقشتها:

عـ 1 عرض وتحليل نتائج الاختبارات القبلية والبعدية للمتغيرات المبحوثة للمجموعة التجريبية جدول ( ع ) يبين الأوسـاط الحسـابية و الانحر افـات المعياريـة وقيمـة ( ت ) المحتسبة للاختبـارين القبلي و البعدي وللمجمو عة التجريبية في الاختبار ات المبحوثة

\begin{tabular}{|c|c|c|c|c|c|c|c|c|}
\hline \multirow{2}{*}{ الدلالة } & \multirow{2}{*}{ 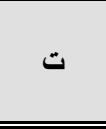 } & \multirow[b]{2}{*}{ مجـف } & \multicolumn{2}{|c|}{ الاختبار البعدي } & \multicolumn{2}{|c|}{ الاختبار القبلي } & \multirow{2}{*}{ الاختبارات البلنية } & \multirow[b]{2}{*}{ 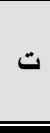 } \\
\hline & & & $\varepsilon$ & س & $\varepsilon$ & س & & \\
\hline مغنوي & $7, \leqslant 1$ & $1 \Lambda, \Lambda$ & $Y, 0 \wedge$ & $r r, q$ & $r, 01$ & 10,1 & الإرسال & 1 \\
\hline معنوي & $1 \leqslant, V \Psi$ & $\overline{1, \lambda \cdot v}$ & $\cdot, 0 \cdot 1$ & $\varepsilon, \leqslant \vee \wedge$ & • & $Y, T Y$ & القارة الانفجارية & $r$ \\
\hline
\end{tabular}

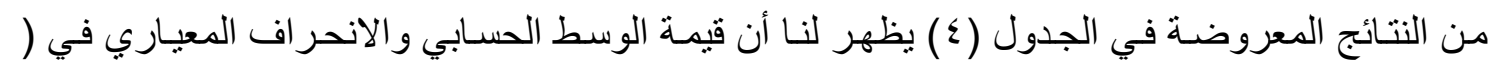

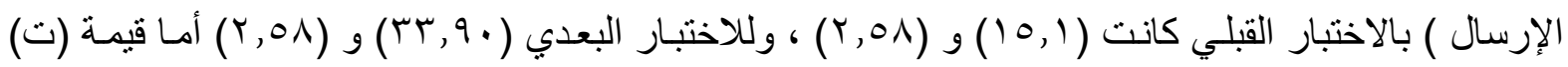

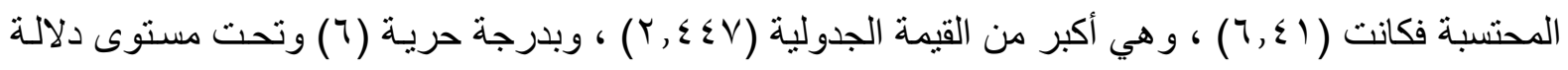
(0. ( • ) ، مما يدل على وجود فروقٍ معنوية لصالح الاختبار البعدي . ويتضح لنا أن قيمة الوسط الحسابي و الانحراف المعياري في ( القدرة الانفجاريـة ) بالاختبار القبلي كانت

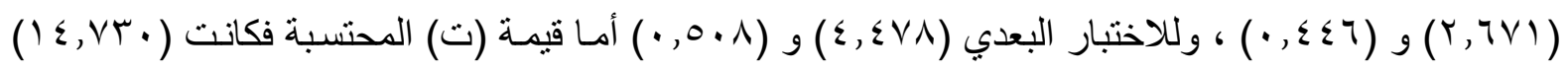

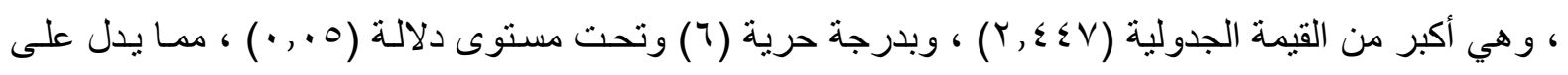
وجود فروقٍ معنوية لصالح الاختبار البعدي . 
ع - عرض و تحليل نتائج الاختبار ات القبلية و البعدية للمتغير ات المبحوثة للمجمو عة الضابطة

جدول ( ه ) يبين الأوسـاط الحسـابية و الانحر افـات المعياريـة وقيمـة ( ت ) المحتسبة للاختبـارين القبلي و البعدي وللمجمو عة الضابطة في الاختبار ات المبحوثة

\begin{tabular}{|c|c|c|c|c|c|c|c|c|}
\hline \multirow[b]{2}{*}{ الدلالة الدالة } & \multirow[b]{2}{*}{ 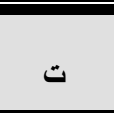 } & \multirow[b]{2}{*}{ مجـ ف } & \multicolumn{2}{|c|}{ الاختبار البعدي } & \multicolumn{2}{|c|}{ الاختبار القبلي } & \multirow[b]{2}{*}{ الاختبارات البدنية والمهارية } & \multirow[b]{2}{*}{ 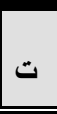 } \\
\hline & & & $\varepsilon$ & س & $\varepsilon$ & س & & \\
\hline مغنوي & $r, 4 \pi$ & $1 \cdot, r$ & $r, 11$ & $r \leqslant, 1$ & $r, 1 \Lambda$ & $1 \%, 1$ & الإرسال & 1 \\
\hline مغنوي & 8,109 & $\cdot, 00 \mathrm{~V}$ & - • & $\mu, \mu \ldots$ & $\cdot, 499$ & $r, V \leqslant Y$ & القُرة الانفجارية & $r$ \\
\hline
\end{tabular}

* قيمة (ت) الجدولية تبلغ (

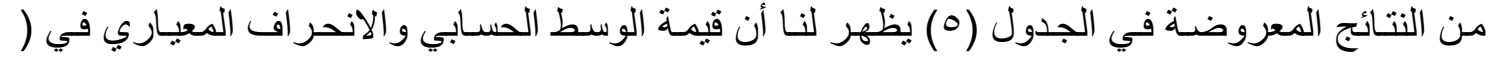

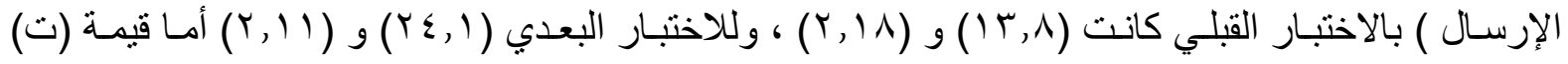

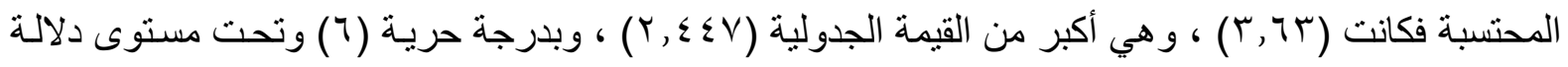
(0. . • ) ، مما يدل على وجود فروقٍ معنوية لصالح الاختبار البعدي .

ويتضح لنا أن قيمة الوسط الحسابي و الانحر اف المعياري في ( القدرة الانفجاريـة ) بالاختبـار القبلي كانت

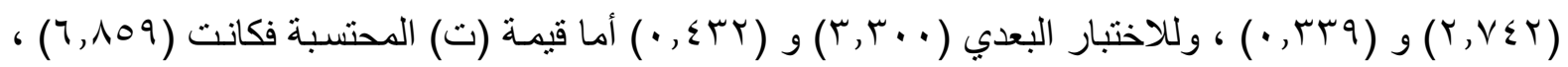

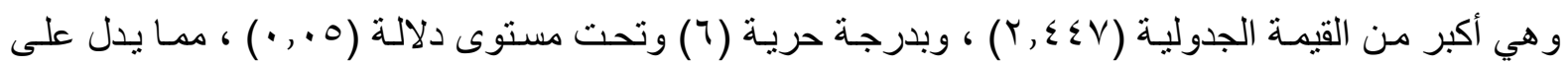
وجود فروقٍ معنوية لصالح الاختبار البعدي .

عـ-r عرض وتحليل نتائج الاختبارات البعدية للمتغيرات المبحوثة للمجموعة الضابطة والتجريبية جدول ( 7 ) يبـين الأوسـاط الحسـابية والانحر افـات المعياريسة وقيمـة ( ت ) المحتسبة للاختبـار البعدي وللمجمو عتين الضابطة والتجريبية في الاختبار ات المبحوثة

\begin{tabular}{|c|c|c|c|c|c|c|c|}
\hline \multirow[b]{2}{*}{ 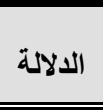 } & \multirow[b]{2}{*}{ * } & \multicolumn{2}{|c|}{ الضابطة } & \multicolumn{2}{|c|}{ التجريبية } & \multirow[b]{2}{*}{ الاختبارات البدنية والمهارية } & \multirow[b]{2}{*}{$ت$} \\
\hline & & $\varepsilon$ & س - س & $\varepsilon$ & س - ن س & & \\
\hline 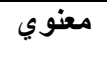 & $v, 991$ & $r, 11$ & $r \leqslant, 1$ & $r, 01$ & $r \mu, q$ & 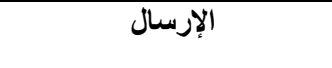 & 1 \\
\hline معنوي & $\varepsilon, 7 \vee 0$ & • & $r, \mu \ldots$ & $\cdot, 0.1$ & $\varepsilon, \xi \vee \wedge$ & القرةة الانفجارية & r \\
\hline
\end{tabular}

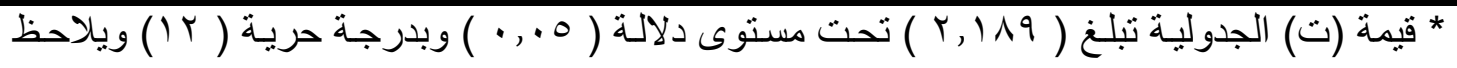

مـن الجدول (ך) للاختبـار ات البعديـة وللمجمـوعتين الضـابطة والتجريبيـة أن هنـاك تـأثير ا”غير معنوي في ( الإرسال ) وللمجموعتين ، ويظهر هذا واضحاءّن خلال فروق الأوسـاط الحسابية للاختبارين ، إذ بلغ الوسط

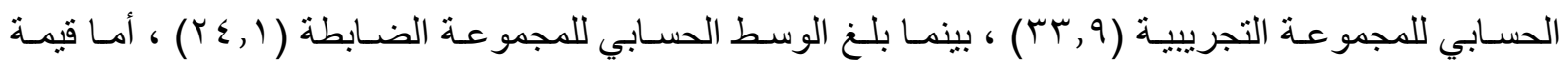

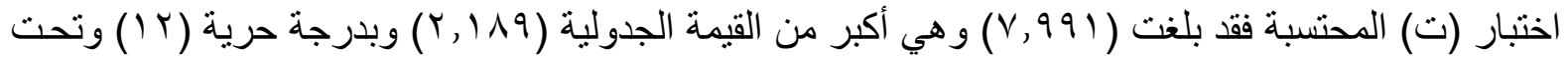
مستوى دلالة (0 . . •) ، مما يدل على وجود فروقٍ معنوية ولصالح المجموعة التجريبية . 


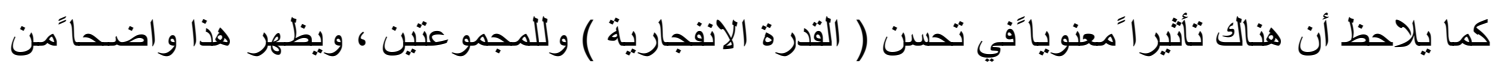

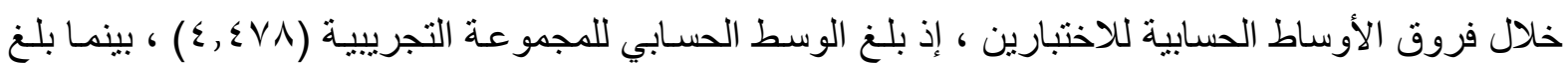

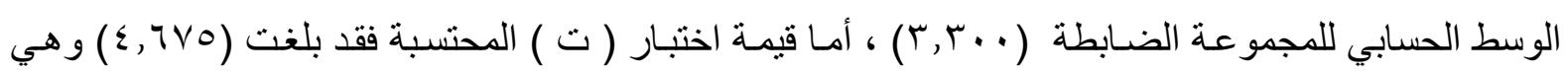

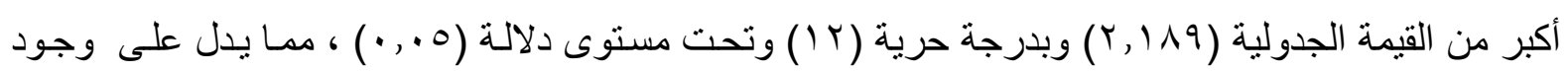
فروقٍ معنوية ولصالح المجمو عة التجريبية.

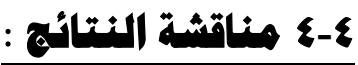

يتضح لنا من الجداول ( ع , 0, ؟) إن هناك تطور في متغيرات البحث الإرسـال , والقدرة الانفجاريـة

للذر اعين) بين القياس القبلي والبعدي للمجمو عتين الضـابطة والتجريبية ولصـالح الاختبار البعدي وكمـا توجد فروق دالة إحصائياً للمتغير ات المبحوثة بين القياس البعدي للمجموعتين ولصـالح المجموعة التجريبيـة ويعزو الباحث سبب التطور الحاصل للمجموعة التجريبية في (دقة الإرسال) لاستخدام التمرينات الخاصة المبنية على في وفق أسس علمية مدروسة والتدرج فيها أثناء تطبيقها وبتكرارات وبشدد مناسبة مع إمكانيات اللاعبين وتمرينات مشابهة للأداء مما زاد من إتقان المهارة والوصول بها إلى هذا المستوى إذ أن إستخدام التوافق الحركي لفترة طويلة وتكر ار منو اصل سيؤدي إلى التعود على إطـار المسار الحركي و الزماني والمثنالي "(') ويعز الباحث أيضاً تفوق المجموعة التجريبية على المجموعة الضابطة بمتغير (القدرة الانفجاريـة للذر اعين ) إلى التمرينات التي وضعها الباحث معتمد بذلك على أساسيات التدريب الرياضـي من حيث الثدد و التكر ارات المناسبة للعينة حيث إن شملت تمرينات القدرة الانفجارية بأسلوب جديد في زيادة القوة والسرعة في آن واحد و عمليات الرمي بالذر اعين وجميعها قد ساهمت بشكل كبير في تطوير القدرة الانفجارية للذر اعين مما انعكس على تحسين الأداء المهاري للإرسال من خلال رمي الكرات الطبية والثقل بأوضاع مختلفة والتي عززت تحميل العضلات لأحمال الإطالة التي بدورها قامت بتطوير الكفايـة لعلاقة المد والقصر في العضلة وكذلك عند تطوير القوة العضلية للاعب ، وذكر (قاسم حسن الإطل 991 ( أن سرعة الحركة هي نتيجة القوة العضلية ، وهذا مـا تؤكده حقيقة الاعتقاد

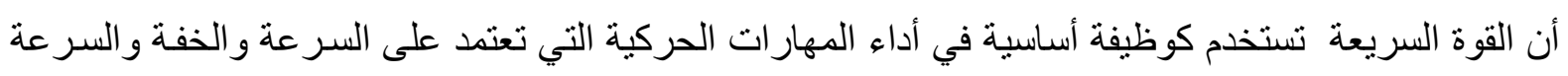

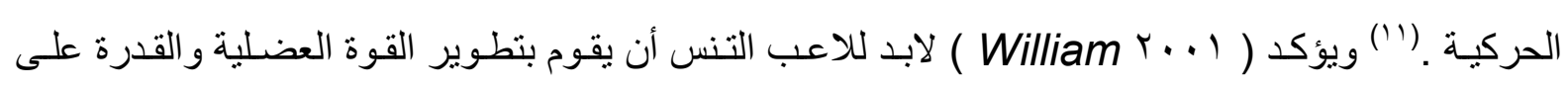

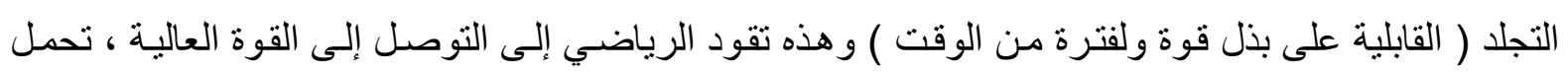

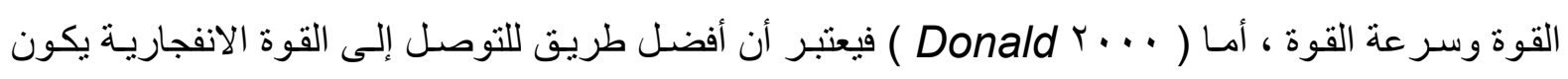

باستخدام تمرينات الأثقال و المقاومات (r')

الباب الخاهس

الاستنتاجات والتوصيات : التوات

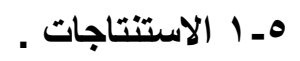

توصل الباحث إلى الاستتناجات المختصرة الآتية :-

ظهور تأثثر إيجابي في تطور القرة الانفجارية للذر اعين باستخدام التمارين الخاصة للمجموعة التجرييية 
ظهور تأثثير إيجابي في تطور دقة الإرسال من جراء تطور القدرة الانفجارية للذراعين باستخدام التمارين

الخاصة للمجمو عة التجريبية.

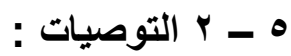

في ضوء الاستتناجات التي توصلت إليها الباحث تم وضع التوصيات الآتية :-

ا ـ ضرورة التأكيد على إستخدام تمارين متنوعة لتطوير القوة الانفجارية للذر اعين للإسهام في تطوير القدرات البدنية و المهارية للاعبي التنس من الناشئين وبنسب مختلفة .

ז- إجراء محاو لات لإستخدام التمرينات المعدة من قبل الباحث على المهار ات الأخرى بلعبة التنس الأرضي الانفجارية أو القوة المميزة بالسر عة والتي تلاعم مستوى وقابليات اللاعبين وحسب فئاتهم .

rـ التتويع في استخدام تمـارين القوة ( الأثقال ـ مقاومـات ـ البلايومترك - حبال مطاطية) وحسب تكرارات وشدد مختلفة . ـ- إجر اء در اسة مشابهة على العاب وفعاليات أخرى .

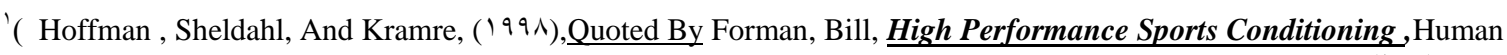
Kentics Publishers, inc. $r \cdots$. . Po .

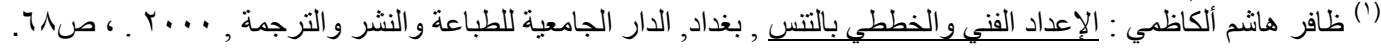
' Http://Fit $\leq$ Tennis Plyometrics - Speed Plus Strength= Power \& Results. Com . r. . r.p.)

Op. Cit, r...,p. `. ..Steven, Scott Plisk, ${ }^{r}$

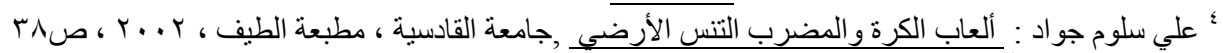

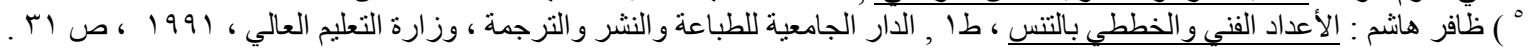
'( William, Donald, Quted By Forman, Bill, High Derformance Sports Conditioning, Human Kentics, Inc.

r... , Part. , p.l.

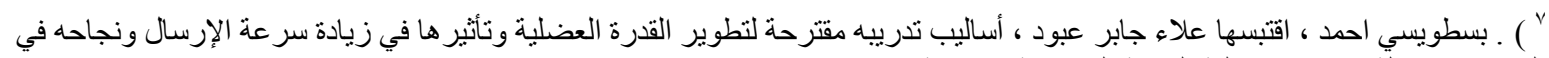

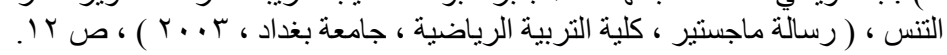

^ Johnson, B. And Nelson, Practical Measurement For Evaluation In Phy. Ed, Minnesota, Publisher co. 19y \&, p. Ү...

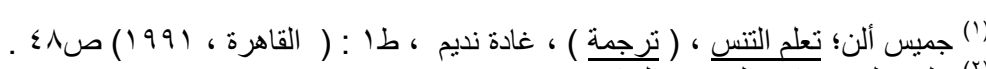

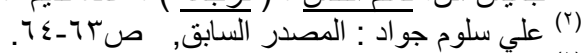

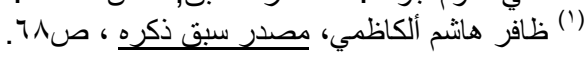

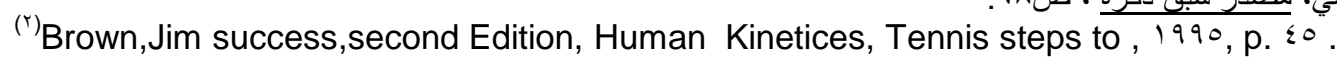

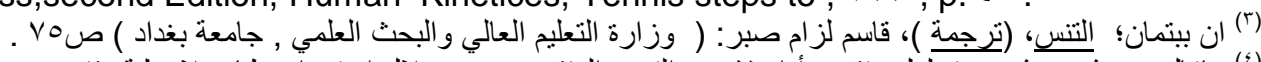

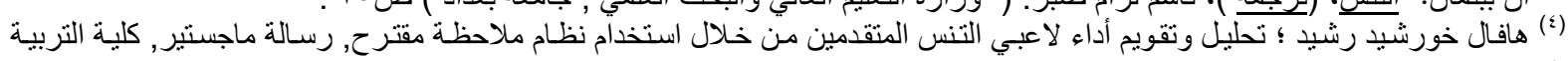

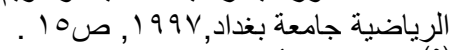

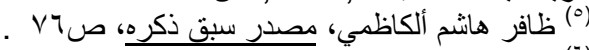

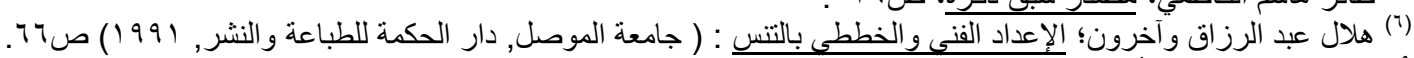

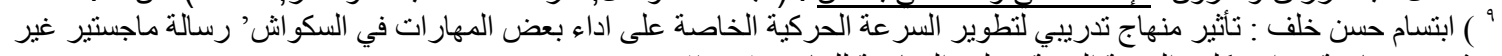

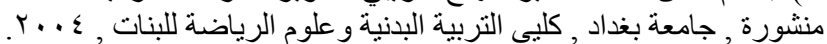

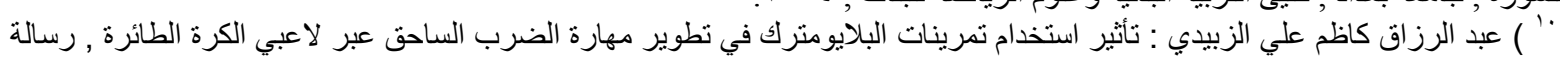

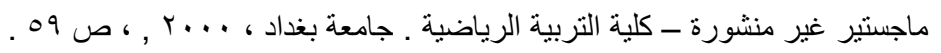

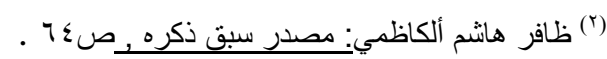

$$
\begin{aligned}
& \text { الاتحاد الفرعي بابل } \\
& \text { الاتحاد الفرعي كربلاء باديل } \\
& \text { حكم حكم }
\end{aligned}
$$

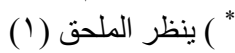




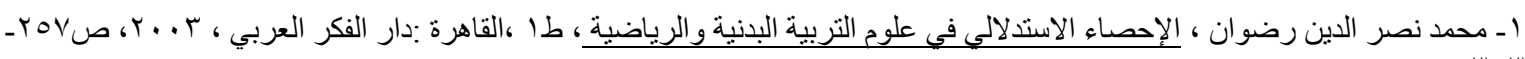

('Owen,Bandclavc,N,Beginnes.Guidetosorc Tanning and :Couning Pelher book Ltd, London, 19v०,P. IT.

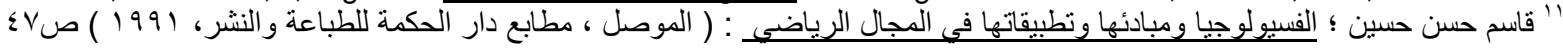

${ }^{\prime r}$ ( . William, Donald, Quted By Forman, Bill, High Derformance Sports Conditioning, Human Kentics, Inc. r... ,

Part. 1, p.l.

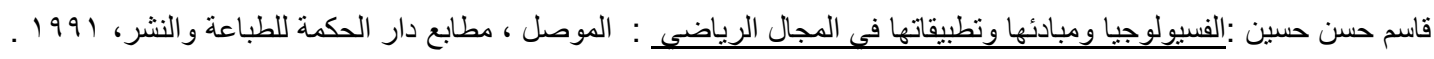
ابتسام حسن خلف : ناثير منهاج تدريبي لتطوير السرعة الحركية الخاصة على اداء بعض المهار ات في السكواش' رسـالة ماجستير غير منشورة

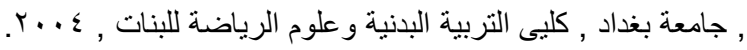

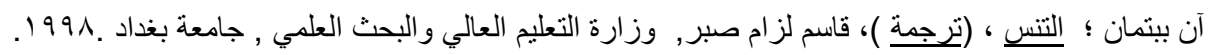

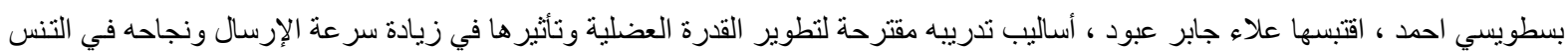

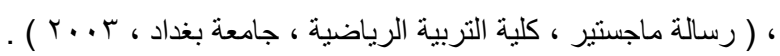

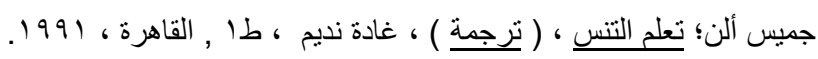

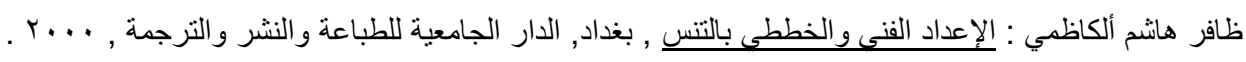

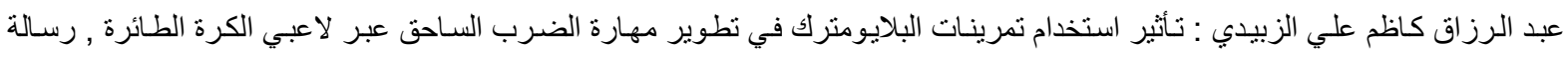

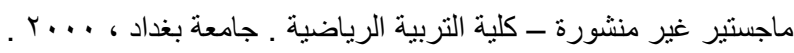

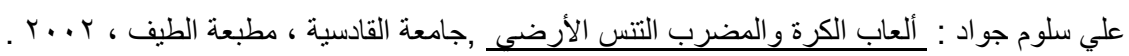

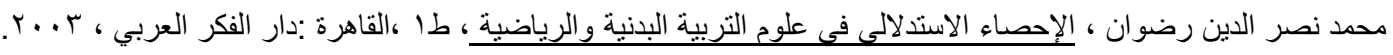
هافال خورشيد رشيد ؛ تحليل وتقويم أداء لاعبي التنس المتقدمين من خلال استخدام نظام ملاحظة مقترح, رسالة ماجستير, كلية التربية الرياضية

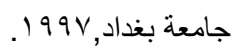

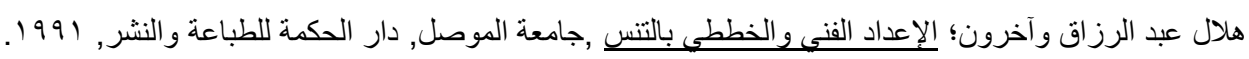
ir- Owen,Bandclavc,N,Beginnes.Guidetosorc Tanning and :Couning Pelher book Ltd, London, 19 vo,.

1 r-Johnson, B. And Nelson, Practical Measurement For Evaluation In Phy. Ed, Minnesota, Publisher co. $19 \vee \varepsilon$,

I $\leq-$ William, Donald, Quted By Forman, Bill, High Derformance Sports Conditioning, Human Kentics, Inc. Y... I, Part. .

10- Brown, Jim success, second Edition, Human Kinetices, Tennis steps to , 1990.

17- Http://Fit $\leq$ Tennis Plyometrics - Speed Plus Strength= Power \& Results. Com . r..r. 
( - Y V - Hoffman, Sheldahl, And Kramre, (199^),Quoted By Forman, Bill, High Performance Sports Conditioning, Human Kentics Publishers, inc. ${ }^{\prime}$. ,

ملحق ( ) أسماء السادة الخبراء الذين أخذ الباحث بأرائهم

\begin{tabular}{|c|c|c|c|c|}
\hline مكان العمل & التخصص & الاسم الكامل & العلقب & $\ddot{~ ت}$ \\
\hline جامعة بابل - كلية التربية البذنية وعلوم & تعلم حركي - العاب مضرب & مازن هادي كزار & 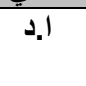 & $T$ \\
\hline جامعة كربلاء - كلية التربية البلنية وعلوم & تعلم حركي - العاب مضرب & وسنام صلاح عبد الحسين & أ.م.د & $r$ \\
\hline جامعة بغاد - كلية التربية البذنية و علوم & تعلم حركي - العاب مضرب & لؤي حسين البكري & أ.م.د & $r$ \\
\hline جامعة بابل - كلية التربية البدنية وعلوم & بايوميكانيك - العاب مضرب & حذيفة ابراهيم احمد & أ.م.د & $\varepsilon$ \\
\hline جامعة بابل - كلية التربية البذنية وعلوم & تلدريب- العاب مضرب & ماهر حمزة حردان & أ.م.د & 0 \\
\hline كلية الهندسة - جامعة بغداد & تعلم حركي / التنس الأرضي & محمد حسن هليل & د. & 7 \\
\hline كلية التربية الرياضية للبنات - جامعة بغداد & التتس الأرضي & حسناء ستار & د.م. & $\mathrm{V}$ \\
\hline
\end{tabular}

$$
\text { ملحق (Y) التمرينات المستخدمة في البحث }
$$

\begin{tabular}{|c|c|}
\hline التمرين & $ت$ \\
\hline رمي كرة طبية وزن ا كيلو من والى الزميل المسافة بينهما ب م. & 1 \\
\hline ضربات بأستخدام المضرب وتكون أمامية وخلفية مع الحائط الأمامي خلال ب اثا. & r \\
\hline من الوقوف دفع كرة طبية زنة ا كفم بكلتا الذراعين نحو الزميل (مناولة صدرية) وترجع بسرعة ويقوة عاليتين & $r$ \\
\hline من وضع الاستناد على الركبتين ، رمي كرة طبية زنة ب كغم من فوق الرأس بكلتا اليدين على الحائط & $\varepsilon$ \\
\hline الوقوف بعرض الأكتاف ، رمي كرة طبية زنة ب كُفم من جاتب الجسم بكلتا الذراعين ، مرة يمين ومرة يسار ثم ترجع بسرعة & 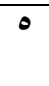 \\
\hline 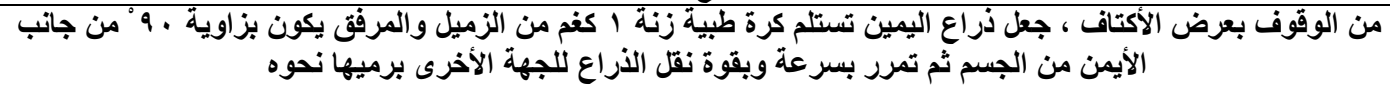 & 7 \\
\hline من وضع الوقوف رمي كرة طبية زنة ب كغم بكلتا الذراعين ومن فوق الرأس وعلى حائط & $\mathrm{V}$ \\
\hline من وضع الوقوف ، رمي كرة طبية ، زنة ب كفم من فوق الرأس وبذراع واحدة على حائط. & $\Lambda$ \\
\hline من الوقوف رمي كرة طية زنة بكفم للخلف ثم الدوران والركض أماماً نحوها بسرعة للقفها بعد سقوطها & 9 \\
\hline 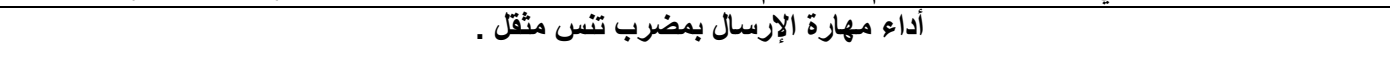 & 1 \\
\hline أداء مهارة الإرسال بكرات تنس طبيعية والتاكيد على إسقاط الكرة فوق القمع الموضوع في منطقة الإرسال. & 1 \\
\hline أداء مهارة الإرسال بمضرب الاسكواش بأقصى قوة . & 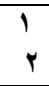 \\
\hline رمي كرة طبية زنة ب كفم نحو الزميل بذراع واحدة ولأبعد مسافة ممكنة والتبديل ومن فوق الرأس ومن وضع الاستناد على & 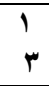 \\
\hline أداء مهارة الإرسال بكرات الاسكواش. . & 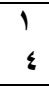 \\
\hline من وضع الاستناد الأمامي وأداء ض ضغات ومن ثم الوقوف وأداء مهارة الإرسال . & $\begin{array}{lll} \\
1 \\
0\end{array}$ \\
\hline
\end{tabular}

ملحق(זّ) نموذج للتمرينات المستخدمة في القسم الرئيسي من الوحدة التدريبية

\begin{tabular}{|c|c|c|c|c|c|c|c|c|}
\hline للتمرين الكلي & التمرين زمن & التراحة بين & المجاميع بين & المجاميع & تكرا & شدة التمرين & التمارين & $ت$ \\
\hline 5190 & ه & ثا. & I & I & $r$ & $\% q$. & تمرين رقم 1 & 1 \\
\hline ثا & هثا & 芒 & ث. & $r$ & 0 & $\% \wedge 0$ & تمرين رقم \& 1 & $r$ \\
\hline ثا 190 & هثا & . & $I$ & $I$ & $r$ & $\% 9$. & تمرين رقم ؛ & $r$ \\
\hline 7 & & & & المجموع & & & & \\
\hline
\end{tabular}




\begin{tabular}{|c|c|c|c|c|c|c|c|}
\hline \multirow[t]{8}{*}{\begin{tabular}{|c|} 
علامة \\
عامة \\
\end{tabular}} & & & & & & & الإعداديم \\
\hline & & & & & & 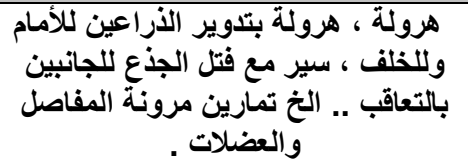 & 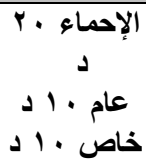 \\
\hline & $\begin{array}{l}0, \\
i . \\
j\end{array}$ & دY, r & $د r$ & 1 & $r \times \mid r$ & 1 - رفع ركبتين للأعلى من الثبات & الرئيسيم القسم \\
\hline & $\begin{array}{l}\text { V } \\
\text { ir } \\
\text { a }\end{array}$ & & $د \leqslant, r$. & r & $\left\{x_{p} \mid 0\right.$ & r- انطلاقات سريعة ه & \\
\hline & د० & & $د r$ & 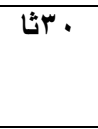 & 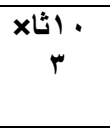 & 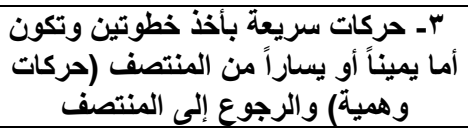 & \\
\hline & $\begin{array}{l}0, \\
10\end{array}$ & & $د r$ & ثان & 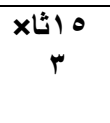 & 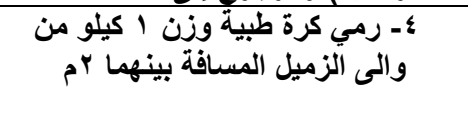 & \\
\hline & $\begin{array}{ll}r \\
r \\
r\end{array}$ & & $د r$ & $د, r$ & r & 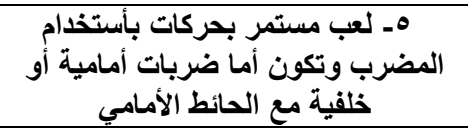 & \\
\hline & & & & & & تمارين تهئية واسترخاء & الختامي \\
\hline
\end{tabular}

